DOI:http://dx.doi.org/10.18524/1810-4215.2019.32.181797

\title{
APPROXIMATION OF THE INTEGRAL ENERGY SPECTRUM OF PROTONS OF SCR IN THE RANGE OF > 1-850 MEV
}

\author{
E.A. Isaeva \\ Institute of Radio astronomy of NAS of Ukraine, isaevaode@gmail.com
}

\begin{abstract}
This work is a continuation of the work (Isaeva E., 2018) in which a new approximation of the integral energy spectrum of solar cosmic ray (SCR) protons was presented in the range $>1-100 \mathrm{MeV}$. In this work, the comments and wishes of colleagues working in this field were taken into account. First, the comments were taken into account on the form of the functional for approximating the energy spectrum of protons, which must correspond in form to the functionals predicted by particle acceleration theories. Secondly, the previously obtained functional should be checked for high-energy protons with energies $>1000 \mathrm{MeV}$.

For the analysis, we used original records of the intensity of the flux of SCR protons according to the data from GOES. The studied sample contains 349 solar proton events (SPE) for the period from 03-02-1986 to 12-02-2018 years, accompanied by protons with energies in the range $>$ 1-850 MeV. Of 349 SPE, 53 were accompanied by highenergy protons with energies $>850 \mathrm{MeV}$.

In this paper, we present the results of approximation of the integral energy spectrum of SCR protons with energies $>1-850 \mathrm{MeV}$ using a functional containing power and exponential functions. A comparative analysis showed that this functional gives a very good approximation for SCR protons with energies in the range $>1-850 \mathrm{MeV}$.
\end{abstract}

Keywords: Proton events, energy spectrum of protons, intensity of the proton flux.

АНОТАЦІЯ. Дана робота $є$ продовженням роботи (Isaeva E., 2018) в якій булла представлена нова апроксимація інтегрального енергетичного спектра протонів сонячних космічних променів (СКП) в діапазоні > 1$100 \mathrm{MeB}$. Уданій роботі були враховані зауваження та побажання колег, які працюють в цій галузі. По-перше, були враховані зауваження що до форми функціоналу для аппроксімаціі енергетичного спектра протонів, який за формою повинен відповідати функціоналам, які пророкують теорії прискорення частинок. Подруге, раніше отриманий функціонал треба перевірити для високоенергічних протонів з енергією $>1000 \mathrm{MeB}$.

Для аналізу були використані оригінальні записи інтенсивності потоку протонів СКП за даними 3 GOES. Досліджувана вибірка містить 349 сонячних протонних подій (СПП) за період з 03-02-1986 по 1202-2018 роки, що супроводжувалися протонами 3 енергією в діапазоні > 1-850 МеВ. 3349 СПП 53 супроводжувалися високоенергійними протонами 3 енергією > $850 \mathrm{MeB}$.

У даній роботі наводяться результати апрокси мації інтегрального енергетичного спектра протонів СКП з енергією > 1-850 МеВ за допомогою функціоналу, що містить ступеневу і експонентну функції.

Порівняльний аналіз показав, що даний функціонал дає дуже гарне наближення для протонів СКП 3 енергією в діапазоні > 1-850 МеВ.

Ключові слова: протонні події, енергетичний спектр протонів, інтенсивність протонного потоку.

\section{Introduction}

Currently, it is believed that SCR can be accelerated either in the region of flare energy release in the current sheets (Melnikov V. et al., 1986; 1991; Nidson A. et al., 2008; Chertok I. et al., 2009) or at the fronts shock waves that can be generated by both flares and coronal mass ejections (CMEs) (Reams D., 1999; Cliver E. et al., 2004). However, the paper (Tsap Yu. And Isaeva E., 2012) provides strong arguments in favor of the model of a two-stage acceleration mechanism proposed half a century ago (Wild J. et al., 1963).

It is known that the shape of the energy spectrum of SCR protons is directly related to particle acceleration mechanisms. In this regard, attempts are made to empirically represent the SCR spectrum based on observational data or on general physical considerations. In fact, obtaining the true spectrum of accelerated particles in the source is a very difficult task (Miroshnichenko L., 2014; 2018). Shock waves in the corona, and then the effects of the transfer of accelerated particles in an interplanetary magnetic field (IMF), associated with the dispersion of particles in velocity, strongly modify the observed spectrum. As a result, the spectrums of SPEs in the Earth's orbit are distinguished by a wide variety of shapes and intensities. Only the spectrum of particles with an energy of $E_{p} \geq 500 \mathrm{MeV}$ approximately corresponds to the spectrum of the source.

Figure 1 shows examples of typical integral energy spectrums of SCR protons with energies in the range $E_{p}>1-850$ $\mathrm{MeV}$ for six SPEs.

Figure 1 clearly shows the significant differences between the events, both in the form of their spectrum and in intensity. The spectrum have a clearly pronounced variable slope, and with increasing energy, the spectrum becomes steeper. An explanation for this behavior has not yet been 
found. It can only be stated that the spectrum can be described above the kink energy by a power-law function with exponential cutoff (Akin 'ian et al., 1983; Ellison et al., 1985). According to (Band et al., 1993; Mewaldt et al., 2005; 2006; 2012), such spectrums are better described by a double power function.
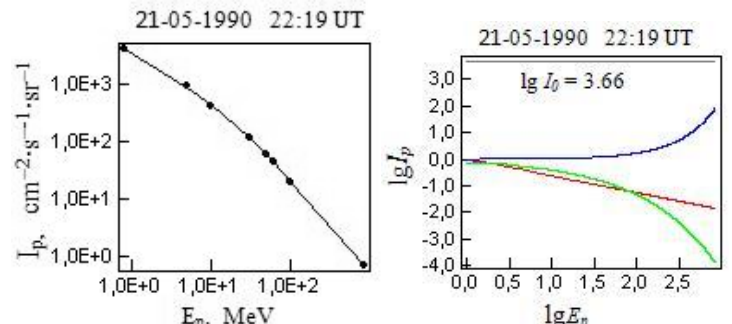

25-06-1992 20:14 UT

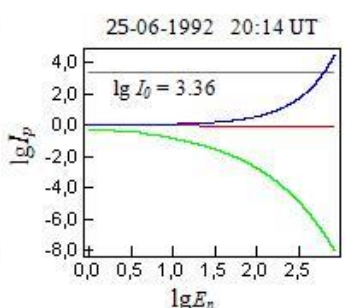

$\lg E_{p}$

22-11-2001 23:30 UT
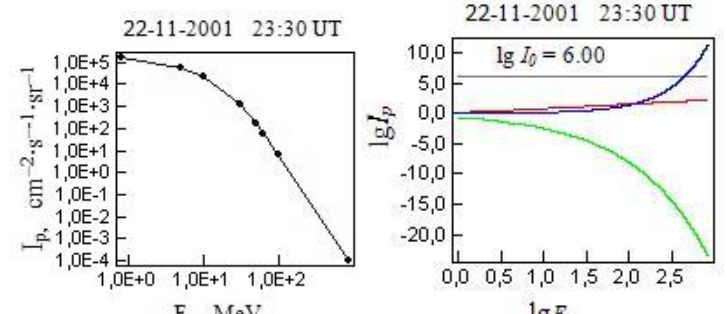

$\lg E_{p}$

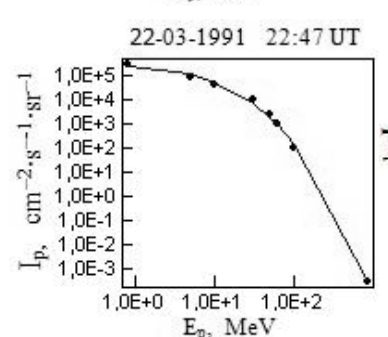

22-03-1991 22:47 UT

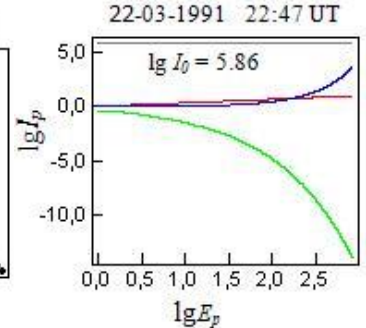

04-11-2001 16:20 UT
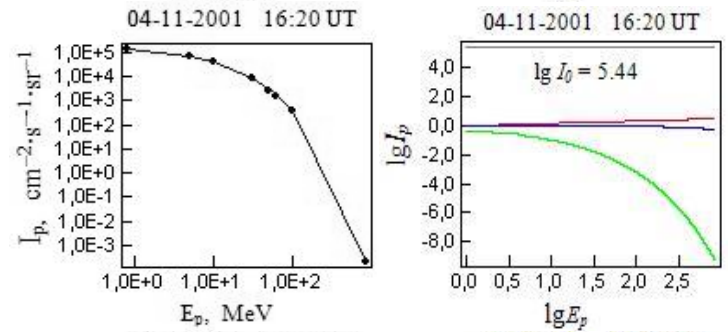

$\lg E_{p}$

10-09-2017 16:06 UT

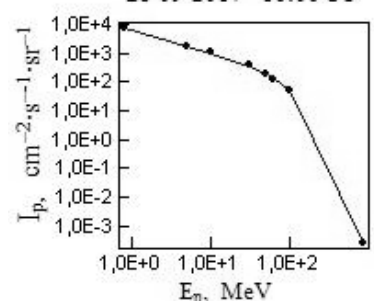

a)

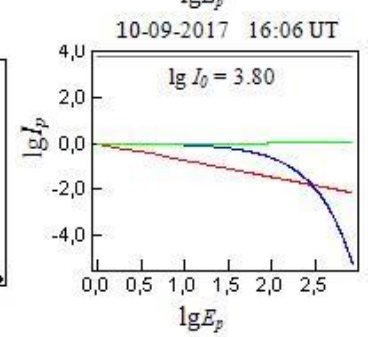

b)
Figure 1: a) Integral energy spectrum of SCR protons. b) The contribution of each parameter in functional (1) in the formation of the integral energy spectrum of protons.
For the analysis, we used the original records of the intensity of the proton flux $I_{p}$ with the energy $E_{p}$ in the range $E_{p}>1$ $850 \mathrm{MeV}$ from data from apparatuses of the GOES series (https://satdat.ngdc.noaa.gov/sem/goes /data/new_avg/), and also a list of solar proton events (SPE). The sample studied contains 349 proton events for the period from 03-02-1986 to 12-02-2018 years. This sample is complete, since it contains almost all events registered for the specified period, including very weak events and superimposed events, which were separated and identified by the author independently. In this connection, errors associated with the separation and identification of proton events are possible. In this sample of 349 SPE 168 events were identified by the author, and the remaining events are present in the SPE directory (ftp://ftp.swpc.noaa. gov/pub/indices/SPE.txt). For all these events, an attempt was made to find a single empirical dependence of the proton flux intensity $I_{p}$ on the proton energy $E_{p}>1-850 \mathrm{MeV}$. To this end, original records of the intensity of the proton flux $I_{p}$ with the energy $E_{p}$ in the range $E_{p}>1$ $850 \mathrm{MeV}$ for all 349 proton events were processed. As a parameter characterizing the proton flux, the maximum intensity of the proton flux $I_{p}$ of a given energy was chosen during the proton event. The value of the $I_{p}$ parameter was calculated from the preflare level. In the case of superposition of proton events, the value of $I_{p}$ was calculated from the level of the previous proton event. Emissions associated with interference and with the imposition of shock waves were also eliminated.

\section{Approximation of the integral energy spectrum of SCR protons in the range $E_{p}>1-850 \mathrm{MeV}$}

In figure 1a) shows the characteristic types of energy spectrum for the SPEs accompanied by high-energy protons with an energy of $E_{p}>850 \mathrm{MeV}$. There are 53 such events in the studied sample. In figure 1a) the energy spectrum of protons are shown, the shape of which gradually changes from an almost rectilinear spectrum to a spectrum with a kink.

In this work, the approximation of the energy spectrum of SCR protons in the range $E_{p}>1-850 \mathrm{MeV}$ was performed using functional (1), which contains power and exponential functions,

$$
I_{p}=10^{d} \cdot E_{p}^{-a} \cdot e^{\left(-b \mathrm{E}_{\mathrm{p}}+c E_{p}^{1 / 2}\right)}
$$

where $a, b, c$ and $d$ are the linear regression coefficients that were found using the least squares method. In figure 1a) the black circles indicate the observed values of the proton flux intensity, and the thin solid black line shows the values calculated using the functional (1).

It can be seen that the approximation of the spectrum using the functional (1) gives a very good approximation.

$$
\begin{aligned}
& I_{0}=10^{d} \\
& I_{p}=E_{p}^{-a} \\
& I_{p}=e^{-b \mathrm{E}_{\mathrm{p}}} \\
& I_{p}=e^{c E_{p}^{1 / 2}}
\end{aligned}
$$


In figure $1 \mathrm{~b}$ ) the contribution of each parameter (2-5) in the functional (1) to the formation of the spectrum is shown. The $\mathrm{X}$ axis represents the decimal logarithms of the proton energy $E_{p}$, and the $\mathrm{Y}$ axis shows the logarithms of the proton flux intensity $I_{p}$. In figure $1 \mathrm{~b}$ ) the gray horizontal line indicates the initial values of the proton flux intensity $I_{0}(2)$, as well as the numerical values of the decimal logarithm $I_{0}$. The red color indicates the contribution of the power function (3) to the formation of the spectrum, and the blue (4) and green (5) colors indicate the contribution from the exponential functions.

In Figure 2 shows the scattering diagrams between the observed and calculated values of the proton flux intensity SCR $I_{p}$ in the range $E_{p}>1-850 \mathrm{MeV}$. Of the 349 proton events, 249 were accompanied by protons with energies $E_{p}>100 \mathrm{MeV}$ and 53 events were accompanied by protons with $E_{p}>850 \mathrm{MeV}$.
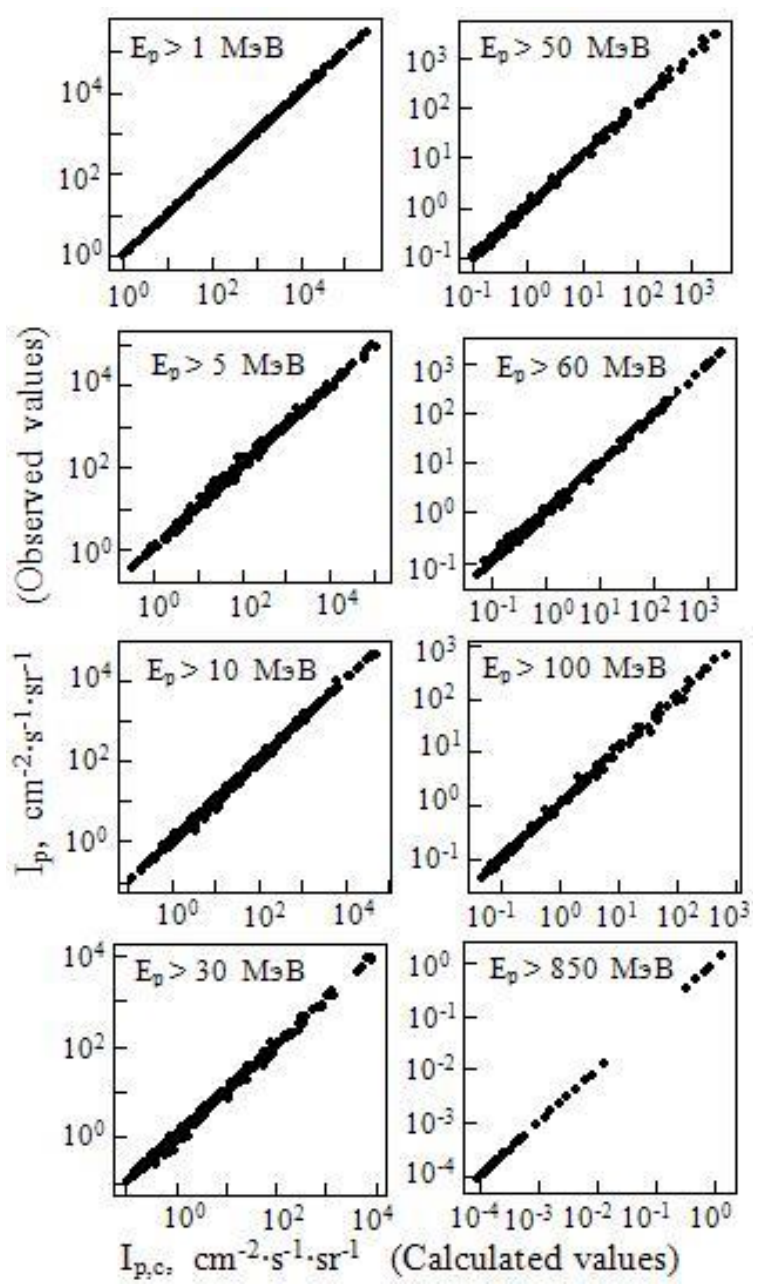

Figure 2: Diagrams of scattering between observed and calculated values of the proton flux intensity SCR.

\section{Conclusion}

A new approximation of the observed energy spectrum of SCR protons in the range $E_{p}>1-850 \mathrm{MeV}$ gives a fairly good approximation. Therefore, a comparison of the observed proton spectrum with the spectrum predicted by SCR acceleration models can be more accurately estimated by the conditions in the acceleration source, as well as the contribution of transport effects in the interplanetary magnetic field, and the additional particle acceleration by coronal and interplanetary shock waves.

\section{References}

Akin ian S., Logachev Iu.: 1983, Catalogue of Solar Proton Events 1970-1979, IZMIRAN.

Band D., Matteson J., Ford L. et al.:1993, Astrophys. J., 413, 281.

Chertok I., Grechnev V., Meshalkina N.: 2009, Astron. Zh., 86, 1133.

Cliver E., Kahler S., Reames D.: 2004, Astrophys. J., 605, 902.

Ellison D., Ramaty R.: 1985, Astrophys. J., 298, 400.

Isaeva E.: 2018, Odessa Astron. Publ., 31, 147.

Melnikov V., Podstrigach T., Kurt V. et al.: 1986, Kosm. Issled., 24, 610.

Melnikov V., Podstrigach T., Daibog E. et al.: 1991, Kosm. Issled., 29, 95.

Mewaldt R., Cohen C., Labrador A. et al.: 2005, Geophys. Res., 110, A09S18.

Mewaldt R.: 2006, Space Sci. Rev., 124, 303.

Mewaldt R., Looper C., Cohen D. et al.: 2012, Space Science Reviews, 171, Issue 1-4, 97.

Miroshnichenko L.: 2014, Solar Cosmic Rays: Fundamentals and Applications 2nd ed., (NewYork: Springer).

Mirishnichenko L.: 2018, Phys. Usp., 61, 323.

Reams D.: 1999, Space Sci. Rev., 90, 413.

Tsap Yu. and Isaeva E.: 2012, Bulletin of the Cremean Astrophysical Observatory, 108, 52.

Tsap Yu. and Isaeva E.: 2012, Geomagnetism and Aeronomy, 52, 921.

Wild J., Smerd S., Weiss A.: 1963, Ann. Rev. Astron. \& Astrophys., 1, 291. 